\title{
Digital Measurement of the Quality of Life of the Russian Population: Aspects of Quality of Health Care
}

\author{
Zoubets A. N., Novikov A.V., Oborskiy A.Y." \\ Financial University under the Government of the Russian Federation, Moscow, Russia \\ "Corresponding author. Email: AYOborskiy@fa.ru
}

\begin{abstract}
The study of the process of improving the quality of life of the Russian population, including the quality of medical care, is connected with the problems of digital assessment of the real state of the quality of life and quality of medical care in Russia. Various theoretical and methodological approaches made it possible to choose the most optimal methodology and research methods, to determine a system of indicators for the digital assessment of the quality of life and quality of medical care for the Russian population. The study used statistical data from the federal authorities of the Russian Federation, the Russian Academy of Sciences, expert estimates on changes in the quality of life of the population in the country, and population surveys. The authors developed approaches for the formation of criteria systems, objective and subjective indicators to optimize the digital assessment of the real state of the quality of medical care in Russia. The quality of life is enhanced by assessments of the real state of quality of life and quality of medical services for the Russian population, as well as practical recommendations proposed by the authors.
\end{abstract}

Keywords: quality of life, quality of medical care, life expectancy, accessibility of high-quality medical care

for the population, responsiveness of the Russian healthcare system to the expectations of the population

\section{INTRODUCTION}

According to the paragraphs 30, 31 of Decree No. 683 of the President of the Russian Federation dated December 31, 2015, "On the National Security Strategy of the Russian Federation", improving the quality of life and strengthening the health of the population are national priorities for the long term, while improving the quality of life of Russian citizens is a national priority of national security of the Russian Federation. In the Russian Federation, improving the quality of life of citizens is guaranteed by ensuring the availability of health system services for the population, creating conditions for stimulating the birth rate, reducing mortality, maintaining a healthy lifestyle, developing popular youth sports, and organizing healthy lifestyle propaganda.

Thus, the most important strategic tasks and criteria for the effectiveness of the country's socio-economic reforms to improve the quality of life in the country are to ensure access to medical care for the population, improve the quality of medical services, increase the responsiveness of the national health system to the expectations of the Russian population. [1-6]

At the same time, in order to identify trends that have a negative impact on improving the quality of life of the population and make optimal management decisions to neutralize them,

it is necessary to know the real state of the processes of changes that make up the quality of life of the population, indicated in digital terms and in digital terms, which requires a certain unified methodology, common methods, common systems of criteria and systems of objective and subjective indicators. As foreign experience in the study of the quality of life of the population shows, when organizing monitoring, subsystems of subjective indicators are especially important, which allow timely identifying public concerns and making the best managerial decision to neutralize social tension.

Paradoxical as it may seem, until now the opinion of the end consumer, the Russian population, about changes in the quality of their life by executive bodies has not been taken into account, no targeted studies of the quality of life of the population of settlements, cities, and regions of the country have been carried out.

The lack of results of such studies (monitoring) extremely negatively affects the quality of budget planning, which leads to inappropriate spending of budget funds and contributes to the emergence of social tension in the country.

\section{MATERIALS AND METHODS}

According to Paragraph 1 of Article 7 of the Constitution of the Russian Federation, the Russian Federation is a social state whose policy is aimed at creating conditions ensuring a decent life and free human development. 
A decent life is that level of life that fully satisfies us, and we can be completely satisfied and happy, and enjoy life. Free human development is the quality of any person in the conditions of modern society to make a choice of education, profession, personal and social aspirations that meet his own ideas about himself and surrounding reality.

Although to date there is no single conventional definition of the category "quality of life", this concept certainly includes the concepts of "decent life", "happiness", "health", "free development of a person", etc., and ensuring the right of every Russian citizen to a decent life and free development of man is one of the most important tasks of the state.

High quality of life for the Russian population is the highest good of a self-valuable and self-sufficient state of life: a phenomenon of happiness, the ultimate goal of developing the socio-economic sphere of Russian society. Ensuring accessibility of the services provided to the population by federal, regional and municipal executive bodies, which shape the quality of life of the Russian population, is a criterion for the effectiveness of the country's socioeconomic reforms.

One of the components of this performance criterion is to improve the quality of work of the national system of Russian health care, ensure sustainable natural growth in the population of the Russian Federation, increase life expectancy, reduce mortality, and reduce poverty in the country.

The achievement of these and other national goals, the solution of the strategic tasks of the development of the Russian Federation, ensuring an increase in the quality of life of the Russian population, is prescribed by the Decree of the President of the Russian Federation of May 07, 2018 "On national goals and strategic tasks of the development of the Russian Federation for the period until 2024".

Studies conducted by the Financial University have shown that the following components of quality of life are of great importance for Russians:

- quality of security and rights of citizens;

- duration and cost of living;

- $\quad$ quality of medical services;

- $\quad$ quality of educational services;

- the quality of the housing system;

- income level sufficient to provide the necessary consumption;

- the quality of the territorial economic and cultural infrastructure.

\section{LITERATURE REVIEW}

The problem of "quality of life" was first discussed in science and in social research in the 60s of the 20th century in connection with issues of public safety, the state of the environment and the preservation of people's health $(R$. Aron, D. Bell, Z. Bzhezinskiy, R. Park, L. Virth, M. Weber, E. Burdgess, J. Rowles, M. Sirgy, G. Samli, A. Meadow, E. Allard, L. Jeffers, J. Dobbs, G. Galbrate, A. Campbell, M. Nussbaum, A. Sen, A. Toynby, E. Fromm).

In the 70-80s of the XX century, in the study of the problem of quality of life, a special place began to be occupied by studies on human rights issues (freedom, democracy, equality, degree of responsibility, etc.).

The research of the quality of life was made by L.I. Abalkin, G.V. A.G. Aganbegian, S.A. Ayvazyan, V.G. Alekseeva, V.N. Bobkov, V.I. Verkhovin, Z.T. Golenkova, T.I. Zaslavskaya, V.K. Levashov, D.S. Lvov, O.A. Mukhanova, V.D. Patrushev, V.V. Radaev, N.M. Rymashevskaya, R.V. Ryvkina, J.T. Toshchenko, N.P. Fedorenko, V.A. Yadov, etc.

The work devoted to studies of the interdependence of quality of life and the organization of a healthy lifestyle was implemented by I.I. Brekhman, Y.P. Lisitsin, S.B. Dobchinov, etc.

The problems associated with the social management of the processes of forming a healthy lifestyle were considered by V.K. Bochkarev, J.V. Kirianova, N.n. Klintsova, P.D. Kosinskiy, V.I. Savinkov, A.S. Yakunin, etc.

However, it should be noted that in modern Russian scientific literature is not sufficiently developed:

- $\quad$ theoretical and methodological approaches to a comprehensive study of the quality of life of the Russian population;

- methodology and methods for digital assessment of socio-economic processes that make up the quality of life, including the quality of medical and educational services;

- $\quad$ adaptation strategies of various social groups and population groups to changes in the quality of life. [7-13]

\section{RESULTS}

Different approaches to assessing the quality of life are usually grouped around the following parameters:

- $\quad$ average life expectancy;

- $\quad$ accessibility of health services for the population;

- financial burden on household budgets.

For example, Table 1 shows comparative data on the main indicators of the quality of medical care (average indicators for 2000-2019) in Russia, the EU, OECD, and the world average.

An analysis of World Bank data for countries of the world showed that the factors listed in Table 2 have the greatest impact on average life expectancy 
Table 1 Comparative data on the main indicators of the quality of medical care (average indicators for 20002019) in Russia, the EU, OECD, and the world average

\begin{tabular}{|c|c|c|c|c|}
\hline Indicator & $\mathrm{EU}$ & OECD & Russia & World average \\
\hline Average per capita health expenditure from all sources, PPP dollars & 2920.0 & 3792.6 & 917.7 & 953.1 \\
\hline Life expectancy at birth, years & 81.4 & 80.5 & 68.1 & 71.3 \\
\hline $\begin{array}{l}\text { Health expenditures from household budgets, PPP dollars per person per } \\
\text { year }\end{array}$ & 443.5 & 575.6 & 307.5 & 212.8 \\
\hline $\begin{array}{l}\text { The share of those who fell below the subsistence minimum of } 3.1 \\
\text { dollars at } 2011 \text { PPP prices due to excess medical expenses, } \%\end{array}$ & 0.25 & 0.37 & 0,15 & 2.0 \\
\hline $\begin{array}{l}\text { The proportion of residents spending on medical purposes more than } \\
10 \% \text { of the household budget, } \%\end{array}$ & 8.1 & 7.0 & 4.3 & 12.8 \\
\hline $\begin{array}{l}\text { The proportion of residents spending on medical purposes more than } \\
25 \% \text { of the household budget, } \%\end{array}$ & 1.0 & 1.3 & 0.8 & 2.6 \\
\hline Basic Health Services Availability Index & 79.8 & 81.9 & 61.1 & 62.7 \\
\hline $\begin{array}{l}\text { The proportion of the population for which the cost of surgery may be } \\
\text { excessive, } \% \text { of the population }\end{array}$ & 4.1 & 5.9 & 53.8 & 47.3 \\
\hline $\begin{array}{l}\text { The proportion of the population for which the need to pay for surgery } \\
\text { may lead to poverty, } \% \text { of the population }\end{array}$ & 1.0 & 3.1 & 26.3 & 48.7 \\
\hline
\end{tabular}

Source: World Bank calculation

Table 2 Factors Affecting Life Expectancy

\begin{tabular}{|c|c|c|}
\hline $\begin{array}{l}\text { No. in } \\
\text { sequence }\end{array}$ & Factor Affecting Life Expectancy & $\begin{array}{l}\text { The correlation coefficient between the given parameters } \\
\text { and the average life expectancy at birth, in } \%\end{array}$ \\
\hline 1. & Prevalence of fatal infectious diseases (including tuberculosis) & $74-92$ \\
\hline 2. & $\begin{array}{l}\text { Accessibility of basic medical services aimed, inter alia, at ensuring children's } \\
\text { health, preventing infectious diseases, etc., including the risk of a lack of money for } \\
\text { necessary treatment }\end{array}$ & 88 \\
\hline 3. & $\begin{array}{l}\text { Provision of basic household goods - electricity, clean water for washing hands, } \\
\text { soap, clean water for drinking and centralized sewage }\end{array}$ & $83-90$ \\
\hline 4. & Road traffic deaths & 75 \\
\hline 5. & $\begin{array}{l}\text { The number of professional doctors (including surgeons), medical personnel, the } \\
\text { prevalence of special medical infrastructure for childbirth }\end{array}$ & $64-73$ \\
\hline 6. & $\begin{array}{l}\text { Grade of immunization: the proportion of children having the necessary } \\
\text { vaccinations }\end{array}$ & $69-72 \%$ \\
\hline 7. & Household spending on medicine from their own budgets & $71 \%$ \\
\hline 8. & Total per capita budget for healthcare from all sources & $64 \%$ \\
\hline 9. & Household spending on final consumption (living standards) & $67 \%$ \\
\hline
\end{tabular}

Table 3 Attitude to medical care among residents of large and medium-sized Russian cities, \%

\begin{tabular}{|c|c|c|c|c|c|}
\hline \multicolumn{6}{|c|}{ Are you satisfied with the quality of medical care you use? } \\
\hline Name/Year & 2015 & 2016 & 2017 & 2018 & 2019 \\
\hline Fully satisfied & 17 & 20 & 15 & 18 & 17 \\
\hline Rather satisfied & 48 & 46 & 52 & 50 & 50 \\
\hline Rather not satisfied & 23 & 23 & 21 & 21 & 22 \\
\hline Absolutely not satisfied & 10 & 10 & 11 & 11 & 11 \\
\hline $\begin{array}{l}\text { The proportion of those } \\
\text { with the quality of medi } \\
\text { personally }\end{array}$ & 65 & 65 & 65 & $68-70$ & 67 \\
\hline \multicolumn{6}{|c|}{ Satisfaction with the quality of medical care by type of medical institution } \\
\hline Free medicine & 64 & 64 & 65 & 65 & 64 \\
\hline Insurance medicine & 69 & 76 & 85 & 81 & 81 \\
\hline Paid medicine & 64 & 65 & 68 & 72 & 73 \\
\hline
\end{tabular}

Source: University of Finance Research 
Table 4 Appeals of the Russian population for medical assistance to other regions or abroad

\begin{tabular}{|l|c|c|c|c|c|}
\hline \multicolumn{6}{|c|}{ Have you, your relatives or friends in recent times, when you had to apply for medical services in another region or abroad?, \% } \\
\hline & $\mathbf{2 0 1 5}$ & $\mathbf{2 0 1 6}$ & $\mathbf{2 0 1 7}$ & $\mathbf{2 0 1 8}$ & $\mathbf{2 0 1 9}$ \\
\hline Yes & 20 & 23 & 23 & 26 & 28 \\
\hline No & 80 & 77 & 77 & 74 & 78 \\
\hline
\end{tabular}

Source: University of Finance Research

Table 5 The ratio of the population to the adequacy of the number of medical facilities in their city

\begin{tabular}{|c|c|c|c|c|c|}
\hline \multicolumn{5}{|c|}{ In your opinion, which medical institutions in your city are missing ?, \% } & \multirow[b]{2}{*}{2019} \\
\hline & 2015 & 2016 & 2017 & 2018 & \\
\hline There are enough medical facilities in the city & 27 & 29 & 33 & 22 & 17 \\
\hline Not enough polyclinics & 25 & 26 & 26 & 27 & 26 \\
\hline Hospitals & 9 & 10 & 8 & 11 & 12 \\
\hline Specialized medical clinics & 14 & 16 & 14 & 18 & 20 \\
\hline Diagnostic centers & 21 & 23 & 20 & 27 & 31 \\
\hline Other & 4 & 3 & 5 & 0 & 0 \\
\hline
\end{tabular}

Source: University of Finance Research 
According to research from the Financial University, the consumer perception of the quality of medical care by the population is shown in table 3 .

According to the studies in tables 4 and 5, there are problems in the country with ensuring the availability of medical services to the population. People are forced to apply for medical services to medical institutions located in other regions of the country or abroad.

Currently, the most scarce for Russians are medical services, which can be presented by general clinics, diagnostic centers, and specialized medical clinics.

It should be noted that at present, studies of the satisfaction of the Russian population with the quality of life, including the quality of medical services provided, are carried out by a number of different state, municipal and public organizations. For each applied research, their own systems of criteria for selecting indicators to assess this social problem are being developed, which is why the obtained research results are fragmented in nature, which does not allow a complete picture of the assessment of the quality of life.

In addition, it is not possible to compare the results of irregularly conducted studies obtained using various methods and various tools. This makes it impossible to analyze dynamic changes in the quality of life, including the provision of medical services on an outpatient basis, in a day hospital and inpatient conditions, in the context of emergency medical care.

The main components of the quality of life standard for the Russian population according to a study conducted by the Financial University of the Government of the Russian Federation are shown in Table 6.

From 2014 to the present, studies have been carried out at the Financial University of the Government of the Russian Federation on the quality of life of the population of Russian cities on the basis of studying the opinions of urban residents on the characteristics of their lives.

In 2019, the studies were conducted in 78 Russian cities with a population of more than $250-500$ thousand people, the number of respondents in each city was at least 600 people. In accordance with the results, the leaders in the overall rating of the quality of life among large and medium-sized Russian cities are: 1. Kazan, 2. Grozny, 3. Tymen, 4. Krasnodar, 5. Moscow, 6. Saint Petersburg, 7. Irkutsk, 8. Sevastopol, 9. Ufa, 10. Kemerovo.[14-20]

\section{DISCUSSION}

After World War II in the USA, due to human losses during military operations and emergency situations that arose, the question arose of compensating the victims for material losses, therefore the concept of "cost of living of an average person" or "cost of living" (value of statistical life, VSL). Subsequently, the estimates obtained began to be used in peaceful areas of human activity.

The "cost" of the average human life (CAL) is a conditional economic value used in solving various socially significant problems. They include:

- $\quad$ assessment of the quality of life in the countries of the world and in different territories: it is believed that the "cost" of human life is directly related to the quality of life of people (the higher the quality of life, the greater its "cost");

- $\quad$ planning of social policy and the possible size of losses;

- planning measures to reduce mortality as a result of industrial and natural emergencies;

- determination of the amount of material compensation to the families of the dead and injured in various emergency situations (ES) of natural and man-made nature;

- $\quad$ planning of insurance coverage of enterprises to compensate for damage caused to personnel and third parties as a result of an emergency, the formation of products of insurance companies, the determination of insurance amounts corresponding to moral and material damage suffered by the victims and families of those who died as a result of an emergency, as well as a number of other tasks.

- The calculated compensation values in connection with the death of a person can be used both for their intended purpose, to determine payments to the families of the deceased, and for various technical and economic calculations related to the planning of social policy or the design of technical systems. 
Table 6 The main components of the quality of life standard for the Russian population according to a study conducted by the Financial University of the Government of the Russian Federation

\begin{tabular}{|l|l|c|}
\hline $\begin{array}{l}\text { No. in } \\
\text { sequence }\end{array}$ & \multicolumn{1}{|c|}{ What goods, in your opinion, should be available to an ordinary Russian family? } & $\begin{array}{c}\text { Share of respondents who named } \\
\text { this option, } \%\end{array}$ \\
\hline 1. & Quality medicine, including paid medicine & 11,7 \\
\hline 2. & Quality education, including paid education & 11.3 \\
\hline 3. & Quality housing: own house, apartment, convenient housing service & 11.0 \\
\hline 4. & High-quality, nutritious meals, including meals outside the home & 10.4 \\
\hline 5. & Good job & 8.7 \\
\hline 6. & Modern household appliances (TV, fridge, washing machine, etc.) & 7.6 \\
\hline 7. & Travel, vacation trips in Russia and abroad & 7.4 \\
\hline 8. & Full access to cultural property (theaters, books, exhibitions, etc.) & 6.9 \\
\hline 9. & Car, development of public transport and the option of free movement & 6.5 \\
\hline 10. & Sports and hobbies & 6.4 \\
\hline 11. & The ability to organize your own life, freedom of choice & \\
\hline 12. & Plenty of free time & 5.8 \\
\hline 13. & Expensive leisure and hobby equipment: SLR camera, for example & \\
\hline 14. & Domestic help (nanny, housekeeper) & 2.5 \\
\hline 15. & Other & 2.2 \\
\hline
\end{tabular}

- For a minimum assessment of the basic "cost" of human life, one can use the size of the material damage caused to society as a whole and the near death of a person.

From a general economic point of view, the "cost of human life" is the total loss of GDP produced due to the death of an average person in an emergency of a different nature. [21-26]

The value is calculated using the following formula: $n$

$$
C A L=\sum_{i=k} D V V P_{i}
$$

where: $C A L$ - the "cost" of the average person's life; $D V V P_{i}$ is the forecast value of per capita of GDP in the $i$-th year at constant prices (excluding inflation);

$k$ is the first year after the premature death of a person; $n$ is the year of the expected "natural" death of a person, provided that he would have lived the number of years corresponding to the average life expectancy of the population (either on average or taking into account gender), and the difference $n-k$ represents the number of years of life "lost" in the result of premature death of a person.

According to formula (1), knowing the age of a particular person at the time of his death, we can estimate the loss of society due to his premature death. You can also assess the average "cost" of human life: the average loss of society due to the death of an average person. Moreover, $k$ - is the year following the current one, and $\mathrm{n}$ is calculated as:

$$
n=k+\alpha-\beta \text {, }
$$

where: $\alpha$ is the average life expectancy of a person today; $\beta$ is the average age of the country's population today. The calculations performed in accordance with this approach give an estimate of the cost of human life as for 2017 in the amount of 31.7 million rubles or 546 thousand USA dollars (prices of 2017). At the same time, the calculations used the assumption about the growth of per capita GDP of Russia after 2018 by an average of $2.5 \%$ in real terms.

The cost of a person's life can also be calculated as the equivalent of the amount of losses incurred by the injured party (in this case, the family, relatives of the deceased) in connection with the death of the person. In this case, the amount of losses can be calculated both in relation to the death of a particular person (taking into account his individual characteristics, first of all, age and income level) and in general, without reference to the individual characteristics of the deceased.

When assessing the "cost" of a person's life as the size of a household's monetary loss due to a person's death, it is necessary to use the expected amount of income minus expenses for own consumption over the number of years equal to the difference between the average life expectancy of a person (either on average or taking into account the gender of the victim ) and the age of the person at the time of his death. Income and own consumption for future periods are calculated on the basis of today's values, taking into account the forecast of growth of indicators in real terms, as well as the expected level of inflation. In general, they can be taken equal to the average per capita income and the cost of living. The income received is discounted taking into account the expected return on investment instruments available to the recipients of reimbursement: for example, ruble deposits with large Russian banks, as well as the expected level of inflation. A more accurate approach is also possible, based on a more complete account of the income structure of the deceased: wages, income from property, business, benefits, pensions, etc.

The final assessment of material damage from human death in emergencies is generally calculated according to the following formula:

$$
\begin{aligned}
& n \\
& C A L=\sum\left(D_{i}-S P_{i}\right) /\left(D X_{i} / I_{i}\right) \\
& i=k
\end{aligned}
$$

where: $C A L$ is the "cost" of the average person's life paid to the family of the deceased at a time; 
$D_{i}$ is the predicted value of the average per capita income in the $i$-th year;

$S P_{i}$ is the forecast value of the average per capita personal consumption in the $i$-th year, in general, the average cost of living

$k$ is the first year after the premature death of a person;

$n$ is the year of the expected "natural" death of a person, provided that he would have lived a number of years corresponding to the average life expectancy of the population;

$D X_{i}$ is the accumulated return on investment of the received one-time compensation in connection with the death of a person from year $k$ to year $i$;

$I_{i}$ is the cumulative inflation from year $k$ to year $i$.

Given a more complete account of the revenue structure, the case is calculated using the following formula:

$$
\begin{gathered}
n \\
C A L=\sum_{i=k}\left(S A L A R Y_{i}-S V M_{i}\right) /\left(D X_{i} / I_{i}\right)+ \\
m \\
\sum\left(P_{i}-P S L_{i}\right) /\left(D X_{i} / I_{i}\right) \\
i=n+1
\end{gathered}
$$

where: $C A L$ is the "cost" of the average person's life paid to the family of the deceased with one payment;

$S A L A R Y_{i}$ is the predicted value of the average wage in the $i$-th year, $S V M_{i}$ is the predicted value of the subsistence minimum of the able-bodied population in the $i$-th year;

$P_{i}$ is the forecast value of the average pension in the $i$-th year;

$V S P_{i}$ is the predicted value of the subsistence level of a pensioner in the $i$-th year;

$k$ is the first year after the premature death of a person;

$n$ is the year of the expected retirement, provided that the deceased would have lived a number of years corresponding to the average life expectancy of the population;

$m$ is the year of the expected "natural" death of a person, provided that he would have lived a number of years corresponding to the average life expectancy of the population;

$D X_{i}$ is the accumulated return on investment of the received one-time compensation in connection with the death of a person from year $k$ to year $i$;

$I_{i}$ is the cumulative inflation from year $k$ to year $i$.

Calculations performed according to formulas (3) and (4) showed that estimates of the "cost" of human life as a household's monetary loss from the death of an average person are 22.5 and 13.2 million rubles, respectively, in 2017 prices.

However, the amount of material damage from the death of a person as a result of an emergency calculated according to formulas (3) and (4) can be used solely as a reference value, which means the minimum amount of compensation, while it does not take into account the moral damage caused to the family by the premature death of a close person.

It should be considered that the above estimates are made for average conditions, and with respect to younger and higher-paid Russians, they can be significantly higher.

The premature death of a person, regardless of the reasons, is a source of suffering for loved ones. The main task of assessing the "cost" of human life for a fair and complete compensation for material and moral damage in connection with the death of a person as a result of an emergency of a technogenic or natural nature is to determine the size of the increase in income that compensates for the average person's life, "lost" due to emergency situations or other reasons. Knowing their ratio, we will determine the "cost" of one year and beyond: of the whole human life (based on its average duration). Using a three-parameter formula for this (life expectancy, income level, life satisfaction) to model the mutual influence of the "lost" years of life and the income necessary to compensate for them is quite justified: both income and life expectancy quite accurately determine the level of people's satisfaction with their existence all over the world, while the largest share of people dissatisfied with their lives is characteristic of countries with per capita consumption of less than 10 thousand dollars per year (at PPP in 2011 prices ode) and life expectancy below 75 years.

Comparison of data on average life expectancy, per capita consumption and life satisfaction makes it possible to estimate the increase in consumption, which can compensate for the "loss" of a certain number of years of life caused by various emergencies and other reasons. And this, in turn, allows us to calculate the "cost" of all human life. Regression analysis of data series on life expectancy, per capita consumption, and life satisfaction across the world allows us to establish that the proportion of citizens satisfied with their lives, average life expectancy, and per capita consumption on average across the world are related by the following relationship:

$$
D S L=-0.71 * K P-0.57 * L E+77.7
$$

where: $D S L$ is the proportion of the country's inhabitants dissatisfied with their life;

$K P$ - per capita spending on household final consumption; $L E$ is average life expectancy;

The task of calculating compensation in connection with a decrease in the duration of human life is to find the size of the increase in the annual size of per capita consumption, which compensates for this decrease in life expectancy and brings population satisfaction to the previous level:

$$
\begin{aligned}
& -0.71 *(K P+\Delta K P)-0.57 *(L E-\Delta L E)=-0.71 * K P \text { - } \\
& 0.57 * L E
\end{aligned}
$$

where: $\Delta L E$ is the decrease in the average life expectancy of the population;

$\triangle K P$ is an increase in per capita expenditures for the final consumption of households, necessary to compensate for the loss of the average life expectancy of a person.

From the formula (6) by simple calculations we obtain the ratio that determines the size of the increase in final consumption:

$\Delta K P=0.57 / 0.71 * \Delta L E$

From formula (7) it is easy to determine that the annual compensation for the loss of one year of life, bringing the level of satisfaction with life to its original position, which existed before the decrease in life expectancy (the "cost" of 


\section{ACKNOWLEDGMENT}

dollars per year in 2011 prices.

Compensation for one year of lost life expectancy throughout a person's life is 57.1 thousand US dollars (with an average world expected life expectancy of a person of 72 years). Based on this, it is possible to calculate the conditional value of the "cost" of human life: it amounts to 4.1 million US dollars in 2011 prices.

It is curious that if we make a similar calculation for the countries of the world with per capita consumption of less than 10 thousand dollars per year, the value of human life will be 0.502 million dollars. And in the group of countries with per capita consumption of more than 10 thousand dollars a year, the "cost" of human life is 14.8 million dollars.

Thus, the total "cost" of human life in the world as a whole is 4.1-5.4 million US dollars in 2011 prices. In the group of countries with per capita consumption of more than 10 thousand dollars a year, the "cost" of life increases to 14.8 million dollars. In the group of countries with income below this mark, the "cost" of life is 0.5-1.9 million dollars.

Calculations based on data on the dynamics of life satisfaction in Russia, per capita consumption and life expectancy in 2005-2015 show that the "cost" of life in our country is 38.2 million rubles. Calculations based on data on life expectancy, population incomes and migration flows for the Russian regions in 2010-2016 showed that the "cost" of human life is 27.3 million rubles. [27-29]

\section{CONCLUSION}

At the moment, the level of quality of life in Russia cannot be recognized as complying with international standards. An analysis of the theoretical and methodological approaches that were established in modern science to assess the quality of life, including the provision of medical services, has shown that problems in ensuring an increase in the quality of life of the population exist in all economically developed countries of the world, and they depend mainly on the prevailing the level of inequality and social injustice in each country.

\section{RECOMMENDATIONS}

In order to improve the quality of life of the Russian population, it is necessary to carry out the necessary research work and, based on the developed scientific and practical recommendations, take the necessary managerial decisions at the level of the Government of the Russian Federation. Studies of the quality of life in all regions of Russia should be carried out according to a unified methodology using the same tools, which will provide an opportunity to compare the results obtained for all subjects of the Russian Federation.
This article was prepared at the Financial University of the Government of the Russian Federation as part of the state assignment of the Government of the Russian Federation for 2020 on the topic of research "The quality of life of the population as a factor of national security and an instrument for achieving the goals of sustainable development of the Russian Federation"

\section{REFERENCES}

[1] Aganbegyan A.G. $\mathrm{O}$ tselyakh i merakh reformirovaniya zdravookhraneniya v Rossii. Voprosy ekonomiki. 2014;(2):149-157.

[2] Aganbegyan A.G. Skol'ko stoit zhizn' cheloveka v Rossii? Ekonomicheskaya politika. 2014;(1):54-66.

[3] Ayvazyan S. A. Integral'nyye indikatory kachestva zhizni naseleniya: ikh postroyeniye $\mathrm{i}$ ispol'zovaniye $\mathrm{v}$ sotsial'no-ekonomicheskom upravlenii i ezhregional'nykh sopostavleniyakh / S.A. Ayvazyan; Ros. akad. nauk, Tsentr. ekon.-mat. in-t. - M.: TSEMI RAN, 2000. - 117 s.

[4] Ayvazyan S. A. Rossiya v mezhstranovom analize sinteticheskikh kategoriy kachestva zhizni naseleniya. Chast' I. Metodologiya analiza i primer yeye primeneniya / S.A. Ayvazyan // Mir Rossii. - 2010. - T. X, No. 4. s. 59-96.

[5] Belyayeva L. A. Uroven' i kachestvo zhizni. Problemy izmereniya i interpretatsii //Sotsiologicheskiye issledovaniya. 2009. No. 1. s. 3-42

[6] Bekker G. Ekonomicheskiy vzglyad na zhizn'. Lektsiya laureata Nobelevskoy premii $\mathrm{v}$ oblasti ekonomicheskikh nauk za 1992 g. Vestnik SanktPeterburgskogo universiteta; 1993. Seriya 5. Vyp. 3.

[7] Glaz'yev S.YU., Lokosov V.V. Otsenka predel'no kriticheskikh pokazateley sostoyaniya rossiyskogo obshchestva i ikh ispol'zovaniye v upravlenii sotsial'noekonomicheskim razvitiyem // Vestnik Rossiyskoy akademii nauk. - 2012. - t. 82. - No. 7. - s. 587-614.

[8] Guriyev S. Mify ekonomiki. Zabluzhdeniya i stereotipy, kotoryye rasprostranyayut SMI i politiki. M:Izd-vo «Mann, Ivanov i Ferber», 2017. 320 s.

[9] Karabchuk T.S., Nikitina M.V., Remezkova V.P. Kak otsenit' stoimost' chelovecheskoy zhizni? 
MPIDR Working Paper. 2016;(006). URL:

Ekononomicheskaya sotsiologiya. T.15. No. 1. Yanvar', 2014. S. $89-106$

[10] Osipov G.V. Izmereniye sotsial'noy real'nosti. Pokazateli i indikatory. M.: ISPI RAN, 2011. -194 s.

[11] 11.Spiridonov, S. P. Indikatory kachestva zhizni i metodologii ikh formirovaniya // Voprosy sovremennoy nauki i praktiki / Universitet im. V. I. Vernadskogo. 2010. No. 10-12 (31). s.208-223.

[12] Ulumbekova G.E. Zdravookhraneniye Rossii. Chto nado delat': nauchnoye obosnovaniye Strategii razvitiya zdravookhraneniya RF do 2020 goda. M.: GEOTARMedia; 2010. 592 s.

[13] Cherkashin A.K. Otsenka kachestva zhizni na osnove resheniya obratnoy zadachi modelirovaniya dinamiki chislennosti naseleniya. Narodonaseleniye. 2014;1 (63):54 - 67.

[14] Agamoni Majumder, S. Madheswaran. Value of Statistical Life: F Meta-Analysis with Mixed Effects Regression Model. The Institute for Social and Economic Change, Bangalore, 2016

[15] Dublin L.I., Lotka A.J. The Money Value of a Man. New York: Ronald Press, 1930.

[16] Krupnick A., Ostro B., Lee R., et. Al. Resources for the Future's Health Benefits Models. December 1994 Report of Resources for the Future, N.W. Washington, D.C., 1994.

[17] Murphy K., Topel R. The Value of Health and Longevity // Journal of Political Economy. 2006. Vol. 114. No 5. P. $871-904$.

[18] Mrozek J., Taylor L. What Determines the Value of Life? A Meta-Analysis // Journal of Policy Analysis and Management. 2001. Vol. 21. No 2. P. 253-270.

[19] Loichinger E., Weber D. Trends in working life expectancy in Europe. Journal of Aging and Health. 2016;28(7):1194-1213.

DOI: $10.1177 / 0898264316656509$.

[20] Kadefors R., Nilsson K., Rylander L., Östergren P.O., Albin M. Occupation, gender and work-life exits: A Swedish population study. Ageing \& Society. 2018;38(7):1332-1349. DOI: $10.1017 / \mathrm{S}$ 0144686X17000083

[21] Myrskylä M., Dudel S., Recent trends in US working life expectancy at age 50 by gender, education, and race/ethnicity and the impact of the Great Recession. Max Planck Institute for Demographic Research. https://www.demogr.mpg.de/papers/working/wp-2016006.pdf (data obrashcheniya: 19.07.2018).

[22] Leinonen T., Martikainen P., Myrskylä M. Working life and retirement expectancies at age 50 by socialclass: Period and cohort trends and projections for Finland. Journals of Gerontology: Series B. Psychological Sciences and Social Sciences. 2018;73(2):302-313. DOI: 15.1093/geronb/gbv104

[23] Value of Statistical life. Best Practice Regulation Guidance Note. Australian Government, Department of the Prime Minister and Cabinet. December, 2014

[24] The Health of Nations: The Value of statistical life. Australian Safety and Compensation Council, March 2016.

[25] 2018 Millennial Cities Ranking [Elektronnyy resurs]. Rezhim dostupa: URL: https://www.nestpick.com/millennial-city-ranking2018/ (data obrashcheniya - 10.01.200

[26] US Department of Transportation. Office of Secretary of Transportation. Guidance of Theatment of the Economic Value of a Statistical Life (VSL) in US Department of Transportation Analyses - 2016 Adjustment.

[27] 27.WHO global report on trends in prevalence of tobacco smoking 2000-2025, second edition. Geneva: World Health Organization; 2018.

[28] 28. The Value of Statistical life: a Meta-Analysis. Environment Directorate. Environment Policy Committee. Working Party on National Environmental Policies Organization for Economic Cooperation and Development 30-Jan-2012

[29] Santos L.D. \& Martins, I (2013). The Monitoring System on Quality of Life of the City of Porto. Community Quality-ofLife Indicators: Best Cases series IV. Springer Dordrecht Heidelberg, New York, London. 